\title{
The Court in the Work of Art: Patronage and Poetic Autonomy in the Orlando Furioso, Canto 42
}

Katherine Hoffman

In the last twenty years, critics have been turning away from a view of the Orlando Furioso as a lovely dream world which celebrates the chivalric ideals of the Renaissance court along with the mythic founders of the Este family of Ferrara, ${ }^{1}$ and exploring instead, beneath the surface of celebration, a remarkably hard-headed analysis of these ideals which corresponds to Ariosto's checkered and sometimes anxious relationship with his patrons Cardinal Ippolito d'Este and Duke Alfonso I. ${ }^{2}$ Both elements, the celebration and the analysis, are important, however-each in fact plays off of the other. The passage I will be discussing here, the description of the castle and fountain which occurs in Canto 42, is a good example of the way that the Furioso manages to combine ostensible celebration with a complex analysis of the patronage system in which Ariosto produced it.

The passage begins halfway through Canto 42, when the knight Rinaldo meets a man in the forest who offers him a place to stay for the night. He is led to a luxurious castle which is described in detail, especially an octagonal marble fountain in the central courtyard sculpted with what is clearly an allegory of poetry: each side has statues of a noblewoman standing on the shoulders of two poets who are singing her praises. These figures are labelled in accompanying scrolls as Ariosto's contemporaries, members of the social and literary circles in which he moved. The eighth side of the fountain, however, shows a single poet supporting a veiled lady, both unnamed. Yet they display the same attitudes of disdain and torment that we have become familiar with in the speaker's references to his own situation elsewhere in the poem. These references date from the speaker's first mention of his lady in the second stanza of Canto 1, in which he claims that his poetic success depends upon her doubtful kindness; they continue, and reach a climax in the astonishing sequence at the end of Canto 29, in which the speaker, having recounted the mad Orlando's pitiful treatment of Angelica's mare, bursts into bitter invective against women, who drive men to such madness-only to apologize at the beginning of the following canto for his own passionate lapse from reason. But he immediately turns things around again, attributing this lapse in turn to his own lady's cruelty:

Date la colpa alla nimica mia, 
che mi fa star, ch'io non potrei star peggio,

e mi fa dir quel di ch'io son poi gramo:

sallo Idio, s'ella ha il torto; essa, s'io l'amo.

$(30.3 .5-8) .^{3}$

The set of circumstances frozen in sculpture on the eighth side of the fountain repeats this familiar pattern; the lady

parea sdegnarsi che con umil canto

ardisse lei lodar sì rozzo ingegno

At this point in the poem a brief reference is enough to invoke the speaker's participation in the frustrated desire that is the quintessential state of being in the Furioso. ${ }^{4}$

On each of the other seven sides of the fountain, an inscription identifies the pair of poets and the lady standing on their shoulders as a famous noblewoman of Ariosto's circle with two of the poets she patronizes. And although their surnames vary, they are in fact all daughters, sisters, and connections by marriage of Cardinal Ippolito and Duke Alfonso d'Este, Ariosto's patrons. The first one, Lucrezia Borgia, was Alfonso's second wife; Isabella and Beatrice d'Este, the Marquise of Mantua and the Duchess of Milan, were Alfonso's and Ippolito's full, legitimate sisters; Lucrezia Bentivoglia was their half-sister; Leonora della Rovere and Elisabetta Gonzaga were Isabella d'Este's daughter and sister-in-law; and Diana Sanseverino was Alfonso's and Ippolito's first cousin. All related to each other by blood or marriage ties with Este men, these women exemplify a web of Este influence radiating out from Alfonso I's generation over the princely courts of northern Italy. Through them we are reminded of the far-ranging power of the Estensi, power maintained through a male line of succession not only by obvious, military means but also through the manipulation of social institutions like matrimony.

In this context, we can see how audacious the speaker is in placing his own lady among these great ones, especially if we take her to represent the woman with whom Ariosto was long connected and eventually secretly married, Alessandra Benucci, who was not his patron but a Florentine bourgeoise. The ladies on the other seven sides derive their social identity from the noblemen whose wives, daughters and sisters they are, and in that role they both inspire and patronize the poets. But the man who would determine the identity and status of the lady on the eighth side is the poet himself; he takes on the double role of both her servant and her would-be master. In other words, there are two contradictory comparisons here: a direct one between the poet of the Furioso and the other poets, as servants; but also an indirect one between the poet and the noble men who are lords and masters of the Este women.

This suggestion of social presumption on the poet-speaker's part extends to the other poets, to courtly poets in general, as well. Poetry is represented 
here in Petrarchan terms, as a male poet's celebration of a lady's beauty and virtue. But the descriptions in the passage and in the scrolls that the poets are holding work against a clear delineation of social hierarchies, in spite of the ladies standing literally on top of the poets and the poets' properly subservient attitudes. The scrolls and descriptions do emphasize fame; but in every case, as in Petrarch, the fame of the poet keeps coming out of the account of the lady's, until it is not at all clear whether poets exist to praise ladies, or ladies exist to give poets the occasion for their famous verses. 5

One hint of this inversion in the ostensible flow of power comes in the first, general description of the fountain, where we learn that the poets have taken care to sign their scrolls "in note non oscure" (42.82.6). But in the individual descriptions, the note of ambivalence becomes cumulatively insistent. The fame of Tebaldeo and Ercole Strozzi rivals that of their patroness Lucrezia Borgia: if she resembles her namesake the Roman Lucrezia in honesty, then they are compared to the mythic poets Linus and Orpheus. Castiglione and Aurelio, the eulogizers of Leonora della Rovere, are described as "ignoti allora, or sì famosi e degni" (42.87.4). Paleotti is compared to Apollo, and Marco Cavallo, in a grand simile, makes Ancona the site of a fount of poetry comparable to the Helicon on Parnassus. Finally, Beatrice d'Este's poets, Correggio and Bendedei, are said to have the power of making the Po stop flowing, like the tears of Phaeton's sisters turned to amber.

In this last reference there is an implication of hubris which might suggest an element of self-conscious parody in these grand comparisons. Phaeton's sisters, after all, were lamenting his death and literal downfall through excessive pride. The other comparisons which sprinkle the passage reinforce this note. Fame is described throughout in terms that mingle art with a particular kind of imperialistic pride: the classical mythology of art goes along with Roman imperial history in particular, and a concern for sheer geographical coverage that recalls imperial ambition generally. These terms apply equally to the ladies and their poets. Mantua reveres the ladies of its current ruling family, Elisabetta Gonzaga and Leonora della Rovere, as much as its native son Virgil, the imperial poet. Silvestri lends fame to his city Pesaro which goes "da l'Indo al Mauro, / e da l'austrine all'iperboree case" (42.89.2-3) and which outdoes its fame as the site of Roman imperial tribute collection from Gaul; poetic fame, in other words, eclipses military fame. Calcagnini spreads the name and glory of Diana Sanseverino, too, throughout the classical empires, "nel regno di Monese [Persia], in quel di Iuba [Mauretania], / in India e Spagna" (42.90.7-8). The total effect of the passage, therefore, is to superimpose a new mythology of imperial art in 16th-century Italy over the classical traditions of Greece and Rome. ${ }^{6}$ In the process, however, the poet subtly takes the place of the imperial conqueror; he is the active one, assuring the extent of his own fame along with his patron's, even as he shows the patrons eclipsing classical heroes. Thus, overall, we can see in the triangular arrangement of the sculptures the possibility of a double interpretation of the 
poet-patron relationship: the poets, in the act of assuring their patrons' fame, actually control it. They may be, literally, beneath the ladies, but they also, again literally, support them in their heights of fame; they control the glory of those who economically and socially control them. Thus the power flows in two directions: outwardly, from the top down, but also, as the imagery of the passage shows, from the bottom up.

This analysis of poetry and patronage relationships, of course, is not new at this point in the Furioso. The fountain in Canto 42 looks back in particular to the famous allegory of poetry on the moon in Canto 35 (1-30), which links poetry and fame. In that passage, St. John's explanation to Astolfo provides an ambiguous interpretation of the relationship between patron and poet that is similar to the interpretation offered by the allegorical fountain in Canto 42. Time throws the names of the dead into the River Lethe, from which only some are rescued by various birds. Ravens, vultures, and daws represent typical courtiers or poetasters, and can only carry the names a little distance before dropping them back into the river. But the two white swans represent true poets, and they alone are able to rescue names and bring them to be enshrined in the temple of immortality. St. John makes a clear distinction between true poets and other sorts of courtiers (the swans as opposed to the other birds), and emphasizes the power that the poets have over their patrons' fame:

Oh bene accorti principi e discreti, che seguite di Cesare l'esempio, e gli scrittor ve fate amici, donde non avete a temer di Lete l'onde!

In stanza $23, \mathrm{St}$. John explains that true poets are as rare as the two swans both because "il ciel" has decided that only a few great rulers should be famous, and because many avaricious rulers let poetic genius go begging rather than patronizing it. The power runs in both directions. But in the following stanzas, St. John's speech more and more emphasizes the poet's power to create reality, to create history, by extolling those who are generous to him, culminating in the outrageous implication that the whole Gospel could be a literary fabrication created by John out of gratitude to his patron, Christ:

$$
\begin{aligned}
& \text { E sopra tutti gli altri [scrittori] io feci acquisto } \\
& \text { che non mi pud levar tempo né morte: } \\
& \text { e ben convenne al mio lodato Cristo } \\
& \text { rendermi guidardon di sì gran sorte. }
\end{aligned}
$$

Yet in stanza 30, St. John's wild, fiery glare as he says this turns into a serene, wise laugh, echoing the balance of stanza 23 , and leaving a space, which has been filled ever since by great critical debate, for interpretation about how far to take the subversive implications. ${ }^{7}$ However we resolve the 
question, the passage effectively raises the issue of poetry and patronage in a broad, indeed cosmic, context of ethics, history and theology. Canto 42 raises the issue again in order to explore the social dynamics of the poetpatron relationship.

The fountain, then, presents an allegory of the profession of poetry as a particular kind of social relationship in 16th-century Italy-a vision of Renaissance Italian society surging up in the middle of Rinaldo's fictional journey. But it is not only the figures on the fountain that are explicitly from the 16th century, the poem's prophetic future. The castle itself, lovingly described over five stanzas in all its ornamental splendor, is in fact recognizable as the Gonzaga ducal palace at Revere, which at the time of the Furioso's writing was newly built on the Po near Mantua. ${ }^{8}$ Ariosto's audience would certainly recognize it, one of the latest extravaganzas in an age of extravagant building. Its richness and ostentation add a physical weight to the vision of the dynastic future which has been prophesied since Canto 3 .

The mysterious host, master of the castle, is another anachronism. He is, in one sense, just a minor character offering a typical romance diversion in Rinaldo's quest. But in stanza 73 the speaker observes that the castle is so splendid that "né a privato uom convenia tanta spesa" (8); in stanza 77, all these riches "mostran che non bastaro a tanta mole / di duo re insieme le ricchezze sole" (8-9). This description, emphasizing his excessive wealth and hinting that he may be more than a private citizen, recalls the terms in which historians such as Burckhardt (24-34) and Lauro Martines (219) have characterized the Renaissance Italian prince. The host thus seems to supply the figure of the male lord and patron that is only implied in the fountain's evocation of Renaissance social hierarchies. But just as the castle is not an Este palace, he remains unidentified, a generic host for a generic castle. The Este patron is never directly implicated.

Stepping back from the whole passage, we can see how it gives a concrete, visual representation of the 16th-century world in which the Furioso was produced-first on a general social level, then on the level of a particular house of the ruling elite, and finally on the level of this particular poem as a product of that society. That is, from the castle, which figures forth architecturally the power and wealth of Renaissance Italian culture, Rinaldo moves to the fountain, which summarizes the sociology of artistic production in the Este court as an example of patronage in that culture; and finally the eighth side of the fountain places the Furioso itself within this context, as the product of a particular poet in a particular social and personal situation. The castle and fountain thus give the future prophesied by Merlin in Canto 3 a direct reality in the world of the poem; at the same time they reinforce the Furioso's account of the Este dynasty's mythic past with a vision of its current fulfillment in Renaissance culture. Yet the insistent note of subversion throughout the passage suggests another, debunking point of view: that this connection between the present and a mythical past is a flatter- 
ing illusion, a literary invention whose ultimate purpose is the poet's social advancement. By focusing on each role in the passage's evocation of the patronage relationship-patron, poet, and lady_in turn, we can perhaps see what these suggestions amount to-where Ariosto finally comes down on the moral questions he seems to raise here.

The careful indirection already noted in the way the passage presents the male lord and patron is strategically necessary, of course, because of the danger of offending him with an analysis of his role which too obviously questions the ideology by which he justifies his power. But although the lord in general, and Ippolito and Alfonso in particular, are notably absent from the passage, the power they wield and represent is omnipresent, forcefully implied by the whole courtly set-up, the grand castle, the rich ladies who are all Este women. This unseen but everywhere obvious presence is perhaps what accounts for the sense of deceptive appearances and watchfulness that pervades the whole passage. The castle's ornamental richness always looks deceiving:

sotto un arco poi s'entra, ove misture

di bel musaico ingannan l'occhio molto.

Or it is hidden:

e oltr'a quel ch'appar, quanti agi sotto

la cava terra il mastro avea ridotto.

[C'erano] pitture e getti, e tant'altro lavoro

(ben che la notte agli occhi il più ne occulti).

Or it seems to watch whoever sees it: from the courtyard Rinaldo

vedeva, e parimente veduta era

da quattro parte de la casa altiera.

This elusive quality corresponds to the intangibility of the power relations between poets and the patron class, and by implication between women and men, to which the fountain gives a physical form; and its sinister aspect suggests serious consequences for resisting that power.

In contrast to the patron, the poet is represented directly in the passage, multiplied by fifteen on the fountain, and enacting the well-known relationship of supplicant to lady in the courtly love tradition of the Petrarchan sonnet. The first seven sides of Ariosto's fountain emphasize that social class provides an insurmountable barrier between poet and lady. But on the eighth side, it is the greatness of the lady's virtue and the insufficiency of the poet's talent (his "rozzo ingegno") that preclude equality and any fulfillment of his 
desire; her awareness of this gap is expressed as disdain. She has the same unattainability as the other seven ladies, but it springs from a natural, not a social, difference; her virtue corresponds to their exalted social rank. But of course the perfect virtue of the seven noblewomen is taken for granted along with their social preeminence. By running together the ideas of natural virtue and social superiority, the fountain taken as a whole reinforces the aristocratic claim, familiar from pastoral literature, that the social hierarchy is natural and ordained. The poet is inspired by the natural moral superiority of the social elite he serves and celebrates. But by confining a completely natural moral superiority, unconnected with social preeminence, to only one side of the fountain, and precisely the side which refers to the Furioso itself, the passage also manages to make the distinction between moral and social superiority. It therefore leaves open the possibility of questioning the hierarchy it seems to promote; the inspiration of this particular poem may not have to do with the social superiority of its patrons at all. The poet's inspiration, the unattainable goal that keeps him writing, is presented here, then, with the same subtle undertones of inversion that we have noted throughout the passage.

But it goes further than that, for the eighth side of the fountain, though it does obviously refer to the Furioso itself, gives an incomplete version of it. The speaker participates in the frustrated or unattainable love which is the poem's major theme, exemplified notably by Orlando and Bradamante. But this way of summarizing the poem leaves out the war between the Christians and the pagans, the great deeds, the magical interventions, the destiny and providence which link the Este to their heroic Carolingian ancestors-in short, its whole epic dimension. Orlando's love-madness is a major, perhaps the major, event of the poem; but it is just as important for holding up decisive epic action as it is for representing a psychological truth about love.

Of course, for Ruggiero and Bradamante, the poem's dynastic heroes, fulfillment of their heart's desire and fulfillment of their epic destiny are one and the same. But throughout the poem, the speaker's completion of the story, which corresponds to the final union of Ruggiero and Bradamante, seems as endlessly deferred and as unattainable as does his much-desired union with his disdainful lady. The poem, when completed, will justify the Este line by establishing the providential authority of its glorious antecedents. But as it continues on for canto after canto with Ruggiero still digressing from his path, the anger and doubt that send Bradamante out on her parallel, frustrating quest to find him seem more and more justified, and the troubling, subversive implications (like the ones underlying this whole passage) pile up. In the Petrarchan situation on the fountain's eighth side, the poet's supposed inspiration-his lady's virtue-frustrates his desire with its disdainful claim of perfection, and thus its impossible distance from his own powers of expression. It is in this gap, between the ideal of moral perfection and the reality of his own human limitations, that the poem is written. Similarly, on the other seven sides, the class of poets who praise ladies work to improve their social 
position in the gap between the aristocratic status they can never attain and the lower social status they have left behind by associating themselves with the elite.

The lady occupies a similarly ambiguous position in this analysis. As an Este wife, daughter, or sister, she is subject to the control of her male relatives and derives her social identity from them. But she also participates in the power of her class, and notably as a patron of the arts. Noble women were more purely the representatives of "high culture," including literary culture and refined values, than male aristocrats, who stood primarily for military and political authority in Renaissance society. The aristocratic lady, carefully protected and controlled, was an aesthetic object in her own right, part of the display of wealth and cultural refinement that her patriarchal society claimed as its hallmarks. The patronage of art was one of the primary roles she fulfilled on behalf of her lord: ${ }^{9}$ Isabella d'Este, for example, was one of the preeminent patrons of her day. Thus the lady, like the poet and his poem, is situated socially somewhere between powerlessness and control. She is coholder of her lord's power, but only in relation to the lower classes, and only in certain areas which he deems less important than the ones that preoccupy him; and she is both in control of and controlled by the poem itself: both the patron-reader who must be pleased, and the voiceless, reified image that the poem and fountain make of her. ${ }^{10}$

There is another figure of the poet implied in the passage, the "mastro diligente e dotto" who sculpted the fountain, presumably for his patron, the host. But unlike the Gonzaga castle that surrounds them, these sculptures have no actual existence outside of the Orlando Furioso; they really exist only as a collection of words in the poem. The artist who made them is in fact the artist of the Furioso-the same one who appears, coyly unnamed, on the fountain's eighth side. We are left with a passage that seems to write itself: the Furioso contains the fountain, which in turn contains the Furioso. This circularity allows Ariosto to evade responsibility for the possible subversiveness of this passage's social analysis, because despite the plethora of poets, the author of this passage is as elusive a figure as the patron. ${ }^{11}$ Just as the relationship between poets and ladies on the fountain both distinguishes natural from social superiority and runs them together, the relationship between poet and patron in the whole passage both makes and obscures the distinction between flattering fiction and true history.

In all of these relationships-poet and lady, lady and lord, poet and patron - the question is raised whether the perfection of the superior is a real, inherent quality, or a flattering construction originating with the inferior, projected onto the superior for sexual or social advancement. The Petrarchan question of the eighth side-does the poet write because of the lady's virtue, or does he attribute virtue to her in order to write?-is raised as a broader social question on the other seven sides: do poets write because of their patrons' inherent virtue and magnificence, and do noblewomen merely reflect 
the virtues of their men, or do they attribute these qualities to them in order to advance socially? By raising this question always indirectly, always by implication, the poet maintains a measure of intellectual freedom, slipping in the possibility of a point of view that is independent of the dominant social ideology, without jeopardizing the only means of expression open to him.

This measure of independence depends on how the patron reads the poem; the power-holder must either miss the implications of the analysis behind the praise, or be willing to tolerate it so long as it is not overt. Thus I would like to end by considering the treatment of the reader in this exposition of poetic production in a patronage system. Rinaldo shows one aspect of this role. His response to the fountain is sheer uncritical wonder, the naive response to poetry which Ariosto always acknowledges (perhaps hopefully) in passages like this. ${ }^{12}$ The absent, omnipresent lord and the lady who stands in for him represent another kind of reader, the powerful reader with a personal stake in the poem who must be pleased. ${ }^{13}$ Yet the kind of reading I have felt free to do here is like neither Rinaldo's nor a patron's. The poet's and the lady's tenuous, hidden, but real potential to see through, and so perhaps to resist, the patriarchal hierarchy that contains them is matched by our ability to read this passage in a way that falls somewhere between uncritical awe at its beauty and complexity, and an egostistical, reductive demand that it reflect us as we wish to see ourselves. It seems to be such readers, ultimately, that Ariosto has in mind: represented in the passage by his peers-the powerful, oppressed poets on the fountain-and the aristocratic ladies-who can also understand an ambivalent social status-and perhaps also, with this poem's overwhelming sense of the literary tradition it both assimilates and helps define, his posterity. We can respond uncritically to this passage, or with reductive self-interest; or we can take our cue from its self-conscious analysis of the patronage system that both constrains and liberates the poet, and see in the balanced ambivalence he feels towards it the analogue of our own ability to respond to the way it weaves together social, aesthetic, and personal elements into a dazzling literary whole.

Roanoke College

\section{NOTES}

1 This is the tradition of Ariosto criticism that runs down through Hegel, De Sanctis, and Croce. It is perhaps most memorably represented among English-language critics by C.S. Lewis's unfavorable comparison of Ariosto to Spenser: "If you stand by Athens and London and Oxford, as I do, then of course Ariosto is not a 'great poet': but if you abandon 'high seriousness,' if brilliance and harmony and sheer technical supremacy are enough, then The Madness of Roland ranks with the Iliad and The Divine Comedy" (303).

2 The shift in critical emphasis toward seeing the Furioso as more actively engaged in moral issues and in its historical, political and cultural context takes a variety of forms, and becomes important starting with Durling's contention that the Furioso consistently balances its apparent evasion of political and historical reality with the urge to confront it (The Figure, 
especially 143-49). Some examples of critics following upon this line of inquiry include Bigi, who sees Ariostan irony achieving a balance between humanistic ideals and harsh political realities; Parker, who argues that Ariosto uses the romance form to challenge the cultural authority associated with the epic; Fichter, whose simplistic and overly positive reading nonetheless focuses on the way that the Furioso reflects and helps create a Renaissance version of epic history; and Bruscagli, who traces in the successive editions of the Furioso a changing attitude toward patronage and authority which corresponds to Ferrara's evolving political situation. Two more recent contributors to this approach are Marinelli, who presents the Furioso as a Neoplatonist reworking of the Innamorato in light of the post-1494 age of crisis, and Ascoli, who explores the Furioso's balancing of "crisis and evasion" on many levels, including the political and cultural. For historical background on the Estensi and Ferraran culture, see Gundersheimer and Chiappini. For further bibliography see Rodini and Di Maria, Ludovico Ariosto, and Rodini, "Selected Bibliography."

3 Textual references are to the Caretti edition of the Furioso.

4 The central text articulating this view of frustrated desire as not only the major theme, but the major structural principle, of the Furioso is Donato.

5 For this view of Petrarch, see Durling, "Petrarch's 'Giovane Donna"' and the introduction to Petrarch's Lyric Poems, as well as Freccero and Mazzotta.

6 This is, of course, the characteristic claim of the Renaissance, announcing itself as a rebirth of classical culture, especially in art and literature: that it both inherits and surpasses the classical tradition, which was being newly perceived as both admirable and fundamentally different from modern, Christian culture. Burckhardt remains the basic text in our understanding of this Renaissance self-perception; for more recent views that are more critical of this perception and attempt to analyze its dynamics and the social and cultural reasons for its coming into being, see Martines, Greenblatt, Quint, and Barkan.

7 Ascoli provides a useful summary of the critical debate over the allegory of fame and poetry on the moon (274-304, especially 291-302 and notes), and argues that Ariosto does not resolve the issue, but presents us with a dialectic between faith and doubt, meaning and unmeaning. For representative readings of this much-interpreted episode, see Durling, The Figure 146-49; Parker 44-46; and Quint, "Astolfo's Voyage." Sergio Zatti's recent book also discusses patronage and the St. John passage, but was unavailable to me as this article went to press.

8 To support this connection, Caretti cites E. Faccioli, "Il Palazzo ducale di Revere e un passo dell'Orlando Furioso," Civiltd Mantovana 1 (1966).

9 Joan Kelly summarizes this role in a discussion of Elisabetta Gonzaga, one of the fountain ladies: "She would not be a prince, she would marry one. Hence her education, like that of most of the daughters of the ruling class, directed her toward the cultural and social function of the court. The lady who married a Renaissance prince became a patron . . . but the court they [the artists] came to ornament was her husband's, and the culture they represented magnified his princely being, especially when his origins could not" (150-51). Kelso (210 65 ) also discusses the lady as patron, in terms of the conflict between the leadership qualities expected of the court lady in practice, and the wifely silence, obedience, and chastity that were the dominant ideal of feminine behavior.

10 Although my focus here is specifically on patronage, the passage also merits a lengthy analysis in terms of gender relations, an issue which runs parallel to social analysis throughout the Furioso. The same ambivalence that the poet feels towards his patrons-both identifying with their power and resenting its control-is consistently attributed to the poem's women, from Angelica to Bradamante to more minor representations such as the women in this passage. The critical literature has only begun to address the Furioso's gender analysis; see Robinson, Shemek, and Wiggins. The speaker's disdainful lady, though regularly sighed for and berated all through the poem, never does relent. And if in the end she is even longer in consenting to her lover than the poem is in bringing its story to completion, it is perhaps 
because she is reserving for herself an autonomy from his male control that corresponds to the measure of independence that he manages to retain from his patron, and that the poem's characters (especially Ruggiero) manage to retain temporarily in the face of destiny, duty, and ultimately, death.

11 For an extended discussion of this circular, evasive quality of the poem's rhetoric, see Ascoli. The slippery evocation of the patronage relationship both on the larger, social level and on the level of this particular poem that I trace in this passage is similar to what Ascoli defines as the Furioso's characteristic dialectic between "crisis and evasion," which he traces more generally in terms of the cultural and political crises of Renaissance Italian society, of the individual crises of Ariosto's or any humanist poet's life and career, and of the crisis of language and referentiality that leads Ariosto to develop in the Furioso "a poetics which continually metamorphoses 'discordia concors' into 'concordia discors' (and vice versa) and which enters into crisis in the very act of fleeing it" (6).

12 Corresponding responses can be found in the poem's other art passages: Bradamante's sanguine reaction to Merlin's prophecy in Canto 3 and to the paintings in the Rocca di Tristano in Canto 33; Ruggiero's, Marfisa's, and the other knights' wonder at the poem's other allegorical fountain in Canto 26; and the wedding party's admiration of the tapestries of Cassandra in Canto 46. In a separate study, I have traced the interaction between these five "prophetic art" passages in the poem as a way of exploring the historiographic aspect of Ariosto's epic--that is, the way that it analyzes the ideological underpinnings of the Este "epic" version of the history of Ferrara and Italy (Hoffman 1-198).

13 Martines cites several examples of the dangers (to career and to life) of displeasing the Este women, especially Isabella d'Este (228). He also relates how Alfonso d'Este had one of the versifiers represented on this fountain, Ercole Strozzi, murdered for apparently intriguing against him.

\section{WORKS CITED}

Ariosto, Ludovico. Orlando Furioso. Ed. Lanfranco Caretti. Torino: Einaudi, 1966.

Ascoli, Albert. Ariosto's Bitter Harmony. Princeton: Princeton UP, 1987.

Barkan, Leonard. The Gods Made Flesh. New Haven: Yale UP, 1986.

Bigi, Emilio. "Ideali umanistici e realtà storica nell'Orlando Furioso." Libri e documenti 2.1 (1976): 1-7.

Bruscagli, Riccardo. Stagioni della civiltd estense. Pisa: Nistri-Lischi, 1983.

Burckhardt, Jacob. Civilization of the Renaissance in Italy. Trans. Samuel G.C. Middlemore. Vienna: The Phaidon Press, 1937.

Chiampi, James F. "Between Voice and Writing: Ariosto's Irony According to Saint John." Italica 83.4 (Winter 1960): 430-50.

Croce, Benedetto. "Ariosto." Ariosto, Shakespeare e Corneille. Bari: Laterza, 1968.

De Sanctis, Francesco. "Ariosto." M.T. Lanza, Ed. Storia della letteratura italiana. Vol. 2. Milano: Feltrinelli, 1964.

Donato, Eugenio. "'Per selve e boschericci labirinti': Desire and Narrative Structure in Ariosto's Orlando Furioso." Patricia Parker and David Quint, Eds. Literary Theory / Renaissance Texts. Baltimore: Johns Hopkins UP, 1986. 33-62.

Durling, Robert. The Figure of the Poet in the Renaissance Epic. Cambridge, MA: Harvard UP, 1965.

$1-20$.

"Petrarch's 'Giovane donna sotto un verde lauro."' MLN 86.1 (Jan. 1971):

Ed. and Trans. "Introduction." Petrarch's Lyric Poems. Cambridge: Harvard

UP, 1976. 1-33.

Fichter, Andrew. Poets Historical. New Haven: Yale UP, 1982.

Freccero, John. "The Fig-tree and the Laurel: Petrarch's Poetics." Diacritics 5 (Spring 1975): $34-40$. 
Greenblatt, Stephen. Renaissance Self-Fashioning. Chicago: U of Chicago P, 1980.

Gundersheimer, Werner. Ferrara: the Stule of a Renaissance Despotism. Princeton: Princeton UP, 1973.

Hegel, Georg Wilhelm Friedrich. Aesthetics. 2 vols. Trans. T.M. Knox. Oxford: Clarendon, 1975.

Hoffman, Katherine A. Reading History in the "Orlando Furioso" and "The Faerie Queene". Diss. Northwestern U, 1991.

Kelly, Joan. "Did Women Have a Renaissance?" Renate Bridenthal and Claudia Koontz, Eds. Becoming Visible: Women in European History. Boston: Houghton Mifflin, 1977:

Kelso, Ruth. Doctrine for the Lady of the Renaissance. Urbana: U of Illinois P, 1956.

Lewis, Clive Staples. The Allegory of Love. Oxford: Oxford UP, 1936. [Rpt. 1979.]

Marinelli, Peter. Ariosto and Boiardo. Columbia: U of Missouri P, 1987.

Martines, Lauro. Power and Imagination: City-States in Renaissance Italy. New York: Vintage/Random House, 1979.

Mazzotta, Giuseppe. "The Canzoniere and the Language of the Self." Studies in Philology 75 (1978): 241-296.

Parker, Patricia. Inescapable Romance. Princeton: Princeton UP, 1979.

Quint, David. “Astolfo's Voyage to the Moon.” Yale Italian Studies 1.4 (Fall 1977): 398-408. Origin and Originality in Renaissance Literature. New Haven: Yale UP, 1983.

Robinson, Lillian S. Monstrous Regiment: The Lady Knight in the Sixteenth-Century Epic. New York and London: Garland, 1985.

Rodini, Robert J. "Selected Bibliography of Ariosto Criticism, 1980-1985." MLN 103.1 (Jan. 1988): 187-203.

and Salvatore Di Maria, Eds. Ludovico Ariosto: An Annotated Bibliography of Criticism, 1956-1980. Columbia: U of Missouri P, 1984.

Shemek, Deanna. "Of Women, Knights, Arms, and Love: The Querelle des Femmes in Ariosto's Poem." MLN 104.I (Jan. 1989): 68-97.

Wiggins, Peter DeSa. "Fables of Gender." Figures in Ariosto's Tapestry: Character and Design in the Orlando Furioso. Baltimore: Johns Hopkins UP, 1986. 161-204.

Zatti, Sergio. Il Furioso fra epos e romanzo. Lucca: Pacini, 1990. 